\title{
Rural Poverty and Credit Use: Evidence from Pakistan
}

\author{
SOHAIL JEHANGIR MALIK and HINA NAZLI
}

\section{INTRODUCTION}

The 1990s have seen poverty reduction become the overarching objective of all economic development. In countries where poverty is largely a rural phenomenon it is obvious that considerations of poverty focus on improving rural welfare. The welfare impact of credit use in the process of agricultural development is generally not explicitly documented in the literature. ${ }^{1}$ The emphasis is generally on "the requisites for development of rural financial policies that facilitate rural growth" [Desai and Mellor (1993)]. Welfare gains arise from this growth through net gains in income from the relaxation of the capital constraint leading to higher input use and resultant higher output, in addition to increasing the risk bearing capacity of households thus leading to the adoption of new technology and diversification of crop mix and income sources. Additionally welfare gains can also arise from credit use directly through improved and more efficient consumption smoothing. Pakistan is predominantly rural and poor. Attempts over several decades, by successive governments, at developing the institutional credit market in Pakistan have failed miserably. The rural credit market continues to be fragmented and beset by distortions. Credit policy aimed at improving access of the small landowners and the poor ended up being diverted to the powerful large landowners. This misuse is widely documented in Malik (1989, 1990 and 1999). Badly designed policies coupled with a weak institutional structure and rampant corruption called into question the very basis for using credit markets as a means for poverty alleviation.

This paper, therefore, attempts to evaluate the underlying relationship between rural poverty and credit use. Using household data collected in 1990 from a

Sohail J. Malik and Hina Nazli are Senior Evaluation Officer, Operations Evaluation Department, The World Bank, Washington, D. C., and Research Economist, Pakistan Institute of Development Economics, Islamabad.

Authors' Note: This paper is extracted from the book Poverty and Rural Credit: The Case of Pakistan by the senior author [Malik (1999)]. Thanks are due to Dr Sarfraz Khan Qureshi, Formerly Director PIDE, for helpful comments in the preparation of the book. The views expressed in this paper are personal.

${ }^{1}$ For an exception to this, see Zeller et al. (1993). 
representative sub-sample of the 1985 Rural Credit Survey of Pakistan households by the International Food Policy Research Institute (IFPRI), this paper looks at whether credit use does, in fact, affect rural welfare. This survey was unique in that it elicited extremely detailed information on household expenditures as well as credit use that permits such an evaluation. The paper examines the key characteristics of credit use patterns by rural households at different levels of poverty and looks at the source structure of such borrowing; thereby highlighting inadequacies in policy and governance of institutional rural credit in Pakistan. In the process it looks at the little known but hugely important role of the village shopkeeper as a source of credit for poverty alleviation through consumption smoothing. The paper is divided into four sections. The second section looks at the welfare impact of credit use. The third section examines the role of the village shopkeeper. The conclusions are summarised in section four.

\section{RURAL CREDIT AND OVERALL WELFARE}

One simple although not widely used method to assess the overall welfare impact of credit use is to compute the standard Foster-Greer-Thorbecke measures of poverty such as the head-count measure $P_{0}$, the poverty gap measure $P_{1}$ and the Foster-Greer-Thorbecke measure with $\alpha=2, P_{2}$, on the basis of an expenditure-based poverty line. A second set of measures can then be computed on the basis of expenditures net of borrowing or credit use based on the same poverty line. The difference between the two sets of measures would indicate the overall welfare impact of participating in the rural credit market. Admittedly, this is a somewhat crude method of showing the overall welfare impact of credit use. However, since the poverty line is estimated on the basis of total expenditure and there is considerable evidence ${ }^{2}$ that the bulk of the borrowing in rural Pakistan is short-term, netting out such borrowing from total expenditure is not too unrealistic.

The poverty line is based on a calorie-expenditure function used to predict the total expenditures ${ }^{3}$ necessary to maintain 2550 calories per adult equivalent of consumption. Details of this methodology can be found in Malik (1991, 1999). These indices are computed by Province and agro-climatic zone within each Province and are presented in Table 1. Details of the methodology and the districts in each agro-climatic zone are available in Malik (1999). The three poverty measures based on the total expenditures are reported in the columns titled "with credit". Expenditures met from borrowing during the year are then netted out of total expenditures and the indices are recomputed. These are reported in the columns titled "net of credit". The indices show, for example, that based on the head count measure, 18.9 percent of the rural households could be classified as poor or below the poverty line. However,

${ }^{2}$ See Malik (1999).

${ }^{3}$ Total expenditures include all repayments on borrowings. 
Table 1

Headcount, Poverty Gap and Foster-Greer-Thorbecke Poverty Measures by Province and Agro-climatic Zones

\begin{tabular}{|c|c|c|c|c|c|c|}
\hline & \multicolumn{2}{|c|}{$\begin{array}{l}\text { Headcount } \\
\text { Measure } \\
\text { (P0) }\end{array}$} & \multicolumn{2}{|c|}{$\begin{array}{l}\text { Poverty Gap } \\
\text { Measure } \\
\text { (P1) }\end{array}$} & \multicolumn{2}{|c|}{$\begin{array}{l}\text { Foster-Greer- } \\
\text { Thorbecke } \\
\text { (P2) }\end{array}$} \\
\hline & $\begin{array}{l}\text { Net of } \\
\text { Credit }\end{array}$ & $\begin{array}{c}\text { With } \\
\text { Credit }\end{array}$ & $\begin{array}{l}\text { Net of } \\
\text { Credit }\end{array}$ & $\begin{array}{c}\text { With } \\
\text { Credit }\end{array}$ & $\begin{array}{l}\text { Net of } \\
\text { Credit }\end{array}$ & $\begin{array}{c}\text { With } \\
\text { Credit }\end{array}$ \\
\hline Pakistan & 0.507 & 0.189 & 0.076 & 0.033 & 0.040 & 0.010 \\
\hline Punjab & 0.455 & 0.173 & 0.067 & 0.032 & 0.034 & 0.010 \\
\hline Rice/Wheat & 0.466 & 0.233 & 0.083 & 0.052 & 0.035 & 0.018 \\
\hline Mixed & 0.368 & 0.184 & 0.074 & 0.040 & 0.039 & 0.015 \\
\hline Cotton/Wheat & 0.449 & 0.254 & 0.089 & 0.041 & 0.042 & 0.010 \\
\hline Low-intensity & 0.541 & 0.173 & 0.061 & 0.026 & 0.028 & 0.006 \\
\hline Barani & 0.483 & 0.085 & 0.044 & 0.014 & 0.028 & 0.005 \\
\hline Sindh & 0.580 & 0.169 & 0.071 & 0.025 & 0.038 & 0.007 \\
\hline Cotton/Wheat & 0.520 & 0.187 & 0.092 & 0.025 & 0.052 & 0.008 \\
\hline Rice/Other & 0.598 & 0.163 & 0.065 & 0.025 & 0.034 & 0.006 \\
\hline NWFP & 0.562 & 0.301 & 0.126 & 0.054 & 0.067 & 0.017 \\
\hline
\end{tabular}

Source: Based on data from IFPRI (1990).

when expenditures met through borrowings are netted out, the head count measures increases to 50.7 percent for Pakistan. This implies that over 30 percent of rural households moved out of poverty merely through credit use. ${ }^{4}$ These data also show that poverty based on the "with credit" definition is highest in NWFP followed by cotton-wheat Punjab. However, based on the "net of credit" definition, poverty is highest in rice/other Sindh followed by NWFP. Similar patterns showing the increase in welfare from credit use in terms of a diminished poverty-gap measure or a significantly smaller Foster-Greer-Thorbecke severity of poverty measure are obvious from the table. The measures reported in this table indicate that borrowing or credit use leads to significant improvement in welfare measured in terms of poverty status and that the extent of credit use considerably alters the relative poverty position of different regions as is obvious from the changing poverty ranks described above.

An alternative method of presenting the same impact is to compute difference of means tests for key items of consumption expenditure between credit-using households and those that do not, controlling for the level of poverty. These difference of means tests can then be re-computed by netting out the credit from the expenditures of the

${ }^{4}$ As will be seen later, the bulk of this credit is short-term from non-institutional sources, especially shopkeepers where repayment rates are almost 100 percent. 
households using credit. A priori, one should expect that there would be no significant differences in the lower expenditure quintiles in mean expenditure levels between households that use credit and those that do not; the argument, confirmed by the results presented in Table 1, being that households borrow especially in the lower levels of poverty to bring their consumption levels up to those of other households in that expenditure level. ${ }^{5}$ One should expect that once these borrowings for the households using credit are netted out, the mean household expenditures for the households not using credit would be significantly higher. These mean household expenditures and test statistics are computed for total household expenditures, consumption expenditures and food expenditures and are reported in Table 2. The table shows that there are no statistically significant differences in mean household expenditures between households with credit and those without credit in the middle expenditure quintiles. The significant differences arise in the lowest expenditure quintile where the mean expenditures of households with credit are significantly higher than households without credit and in the highest expenditure quintile where the mean expenditures of households with credit are significantly lower. However, when the same tests are computed by netting out borrowing during the year from each category of expenditure, the mean levels of expenditures for households without credit are significantly higher in each category. ${ }^{6}$ It should be emphasised that the results based on this methodology probably tend to overestimate somewhat the impact of credit and should, therefore, be interpreted with caution.

The larger body of literature on rural credit focuses on the possibility of increased input use leading to productivity and production increases. This impact can also be assessed using the same difference of means tests approach outlined above. These results are presented in Table 3 where the wider definition of credit use which incorporates the essential elements of the fungibility of credit and the jointness of consumption and production decisions is used. In this case, a household having obtained credit for any purpose is defined as "with credit". Input expenditures include only expenditures on seed, fertiliser and pesticides whereas farm expenditures include all types of expenditure on the farm. An interesting contrast to the results in Table 2 is obtained. In the case of input expenditures and farm expenditures, households with credit generally have a significantly higher level of mean expenditures than those households without credit in the three lowest expenditure quintiles. Moreover, when credit use is netted out of expenditures, we find that the mean level of expenditures are generally similar. This implies that households in the lower expenditure quintiles increase their mean input and farm expenditures through credit use. In terms of the impact on the value of farm output, the

${ }^{5}$ Obviously, the ability to borrow also depends in part, especially in the context of borrowing from formal sources, on the ability to repay and the availability of acceptable collateral. These issues and why it is possible in the Pakistani context for very poor people to borrow will be discussed in subsequent sections.

${ }^{6}$ However, some of these differences will still be explained by wealth effect within each quintile. 
Table 2

Difference of Means Test on Total Household Expenditures, Consumption Expenditures and Food Expenditures (000 Rupees) for Households With and Without Credit by Per Capita Expenditure Quintiles, Pakistan

\begin{tabular}{|c|c|c|c|c|c|c|}
\hline & \multicolumn{5}{|c|}{ Per Capita Expenditure Quintiles } & \multirow[b]{2}{*}{ All } \\
\hline & Lowest & Second & Third & Fourth & Highest & \\
\hline \multicolumn{7}{|c|}{ Total Household Expenditures } \\
\hline Without Credit & $\begin{array}{l}17.46 \\
(1.31)\end{array}$ & $\begin{array}{l}24.61 \\
(2.24)\end{array}$ & $\begin{array}{l}28.33 \\
(2.22)\end{array}$ & $\begin{array}{l}54.31 \\
(6.04)\end{array}$ & $\begin{array}{l}161.40 \\
(22.74)\end{array}$ & $\begin{array}{l}67.83 \\
(7.61)\end{array}$ \\
\hline With Credit & $\begin{array}{l}20.66 \\
(0.76)\end{array}$ & $\begin{array}{l}27.75 \\
(1.00)\end{array}$ & $\begin{array}{l}32.56 \\
(1.39)\end{array}$ & $\begin{array}{l}47.49 \\
(1.90)\end{array}$ & $\begin{array}{l}105.95 \\
(6.94)\end{array}$ & $\begin{array}{l}45.46 \\
(1.70)\end{array}$ \\
\hline T-Statistic & -1.85 & -1.14 & -1.41 & 1.39 & 3.10 & 4.39 \\
\hline \multicolumn{7}{|c|}{$\begin{array}{l}\text { Total Household Expenditures } \\
\text { Net of Credit }\end{array}$} \\
\hline Without Credit & $\begin{array}{l}17.46 \\
(1.31)\end{array}$ & $\begin{array}{l}24.61 \\
(2.24)\end{array}$ & $\begin{array}{l}28.33 \\
(2.22)\end{array}$ & $\begin{array}{l}54.31 \\
(6.04)\end{array}$ & $\begin{array}{l}161.40 \\
(22.74)\end{array}$ & $\begin{array}{l}67.83 \\
(7.61)\end{array}$ \\
\hline With Credit & $\begin{array}{l}14.06 \\
(0.58)\end{array}$ & $\begin{array}{l}19.25 \\
(0.87)\end{array}$ & $\begin{array}{l}25.19 \\
(1.26)\end{array}$ & $\begin{array}{l}37.34 \\
(1.78)\end{array}$ & $\begin{array}{l}84.86 \\
(5.55)\end{array}$ & $\begin{array}{l}34.95 \\
(1.40)\end{array}$ \\
\hline T-Statistic & 2.46 & 2.20 & 1.13 & 3.62 & 4.65 & 7.02 \\
\hline \multicolumn{7}{|c|}{ Consumption Expenditures } \\
\hline Without Credit & $\begin{array}{l}12.86 \\
(1.05)\end{array}$ & $\begin{array}{l}16.37 \\
(1.68)\end{array}$ & $\begin{array}{l}15.83 \\
(1.16)\end{array}$ & $\begin{array}{l}24.87 \\
(2.40)\end{array}$ & $\begin{array}{l}36.31 \\
(7.64)\end{array}$ & $\begin{array}{l}22.81 \\
(2.28)\end{array}$ \\
\hline With Credit & $\begin{array}{l}14.59 \\
(0.55)\end{array}$ & $\begin{array}{l}17.25 \\
(0.65)\end{array}$ & $\begin{array}{l}16.56 \\
(0.65)\end{array}$ & $\begin{array}{l}19.60 \\
(0.62)\end{array}$ & $\begin{array}{l}23.36 \\
(1.52)\end{array}$ & $\begin{array}{l}18.16 \\
(0.39)\end{array}$ \\
\hline T-Statistic & -1.36 & -0.49 & -0.50 & 3.06 & 2.47 & 3.40 \\
\hline \multicolumn{7}{|c|}{$\begin{array}{l}\text { Consumption Expenditures } \\
\text { Net of Credit }\end{array}$} \\
\hline Without Credit & $\begin{array}{l}12.86 \\
(1.05)\end{array}$ & $\begin{array}{l}16.37 \\
(1.68)\end{array}$ & $\begin{array}{l}15.83 \\
(1.16)\end{array}$ & $\begin{array}{l}24.87 \\
(2.40)\end{array}$ & $\begin{array}{l}36.31 \\
(7.64)\end{array}$ & $\begin{array}{l}22.81 \\
(2.28)\end{array}$ \\
\hline With Credit & $\begin{array}{c}9.11 \\
(0.39)\end{array}$ & $\begin{array}{l}11.43 \\
(0.57)\end{array}$ & $\begin{array}{l}11.90 \\
(0.58)\end{array}$ & $\begin{array}{l}14.00 \\
(0.61)\end{array}$ & $\begin{array}{l}18.16 \\
(1.48)\end{array}$ & $\begin{array}{l}12.79 \\
(0.36)\end{array}$ \\
\hline T-Statistic & 3.85 & 3.05 & 3.01 & 6.36 & 3.49 & 7.49 \\
\hline \multicolumn{7}{|c|}{ Food Expenditures } \\
\hline Without Credit & $\begin{array}{c}7.85 \\
(0.62)\end{array}$ & $\begin{array}{c}9.47 \\
(1.03)\end{array}$ & $\begin{array}{c}8.76 \\
(0.65)\end{array}$ & $\begin{array}{l}12.61 \\
(1.18)\end{array}$ & $\begin{array}{l}14.79 \\
(1.53)\end{array}$ & $\begin{array}{l}11.11 \\
(0.56)\end{array}$ \\
\hline With Credit & $\begin{array}{c}9.11 \\
(0.34)\end{array}$ & $\begin{array}{l}10.14 \\
(0.41)\end{array}$ & $\begin{array}{c}9.14 \\
(0.35)\end{array}$ & $\begin{array}{l}10.10 \\
(0.33)\end{array}$ & $\begin{array}{l}11.31 \\
(0.71)\end{array}$ & $\begin{array}{c}9.94 \\
(0.20)\end{array}$ \\
\hline T-Statistic & -1.61 & -0.59 & -0.50 & 2.81 & 2.32 & 2.40 \\
\hline \multicolumn{7}{|c|}{ Food Expenditures Net of Credit } \\
\hline Without Credit & $\begin{array}{c}7.85 \\
(0.62)\end{array}$ & $\begin{array}{c}9.47 \\
(1.03)\end{array}$ & $\begin{array}{c}8.76 \\
(0.65)\end{array}$ & $\begin{array}{c}12.61 \\
(1.18)\end{array}$ & $\begin{array}{l}14.79 \\
(1.53)\end{array}$ & $\begin{array}{l}11.11 \\
(0.56)\end{array}$ \\
\hline With Credit & $\begin{array}{c}4.71 \\
(0.26)\end{array}$ & $\begin{array}{c}5.49 \\
(0.38)\end{array}$ & $\begin{array}{c}5.88 \\
(0.35)\end{array}$ & $\begin{array}{c}5.96 \\
(0.35)\end{array}$ & $\begin{array}{c}7.36 \\
(0.59)\end{array}$ & $\begin{array}{c}5.84 \\
(0.18)\end{array}$ \\
\hline T-Statistic & 4.95 & 3.77 & 3.76 & 7.18 & 5.53 & 11.58 \\
\hline
\end{tabular}

Source: Based on data from IFPRI (1990).

Notes: 1. Households using credit for any expenditures are classified as 'With Credit' otherwise 'Without Credit' households.

2. Figures in parenthesis are respective standard errors. 
Table 3

Difference of Means Test on Input Expenditures, Farm Expenditures and Value of Farm Output (000 Rupees) for Households With and Without Credit by Per Capita Expenditure Quintiles, Pakistan

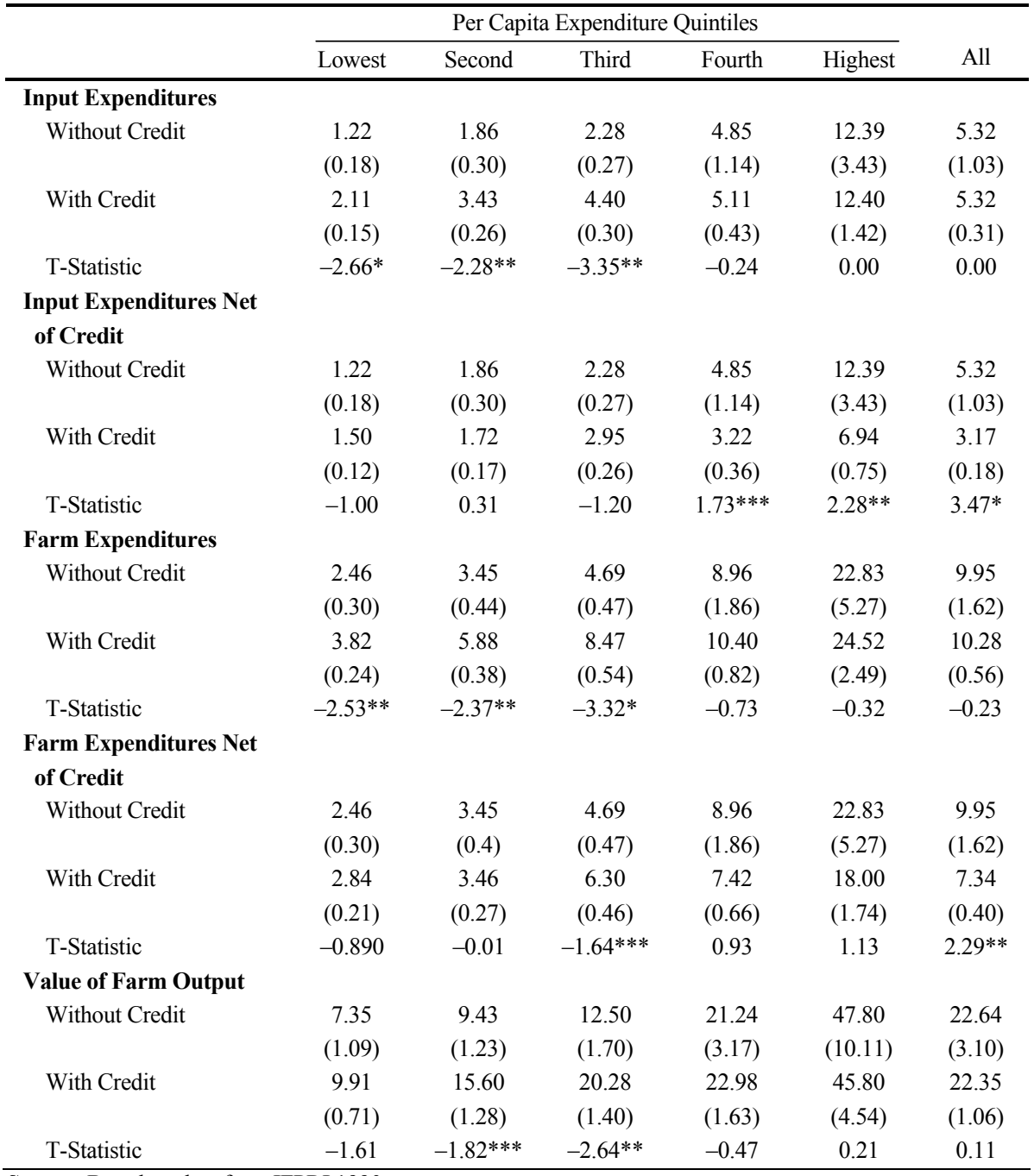

Source: Based on data from IFPRI 1990.

Notes: 1. Households using credit for any expenditures are classified as 'With Credit' otherwise 'Without Credit' households.

2. Figures in parenthesis are respective standard errors.

${ }^{*}$ Indicates significant at 1 percent level.

** Indicates significant at 5 percent level.

${ }^{* * *}$ Indicates significant at 10 percent level. 
results indicate that mean levels are statistically significantly higher for households with credit in the second and third expenditure quintiles.

The results of greater input use and resulting higher value of farm output are strongly reinforced if a stricter definition of households with credit is applied. In this case households that use credit for seed, fertiliser and pesticides are classified as "with credit" and those that do not, are classified as "without credit". These results are presented in Table 4. The results indicate that households with input credit have significantly higher levels of mean input and farm expenditures in each expenditure quintile. Moreover, when credit is netted out of expenditures, the mean input expenditures of households without credit are either higher or similar to those defined as "with credit". The strongest result presented in Table 4 is the significantly higher value of farm output in each expenditure quintile in the case of households with credit. Tables 1 to 4 indicate that credit use has a positive welfare impact in rural Pakistan and leads to higher input use and greater value of output. It is important, therefore, to evaluate the relative importance of credit use on different expenditure items in the farm household budget. These data, presented in Table 5 indicate that a predominant proportion of rural households undertake some form of borrowing. On an aggregate, nearly 81 percent of all rural households reported in this survey borrow for some form of expenditure. It should be re-emphasised that such borrowing includes short-term shopkeeper credit obtained from the village shop, borrowing from landlords against their share of input use by tenants and borrowing from friends and relatives in addition to borrowing from formal sources. In terms of the amount of borrowing, the highest percentage share of credit use is for consumption purposes including food. This proportion is highest in the lower expenditure quintiles. The proportion of amount borrowed for input use and for capital purposes increases significantly in higher expenditure groups as the relative importance of consumption declines.

There are no clear patterns in terms of the proportion of households borrowing within different expenditure purposes except in the case of capital expenditure where the percentage of households using credit generally increases by expenditure groups. The data in Table 5 clearly indicates the extent of credit use in rural Pakistan is high. On an aggregate, over 17 percent of total expenditures are met through borrowing; these proportions are nearly 22 percent and over in the case of input, capital and consumption including food items. It should be borne in mind that the total expenditure category presented in Table 5 covers items in addition to those classified under the three main heads presented in the table. Within the different types of farm expenditures, borrowing from both formal and informal sources is used. However, generally, the proportion of expenditure met from borrowing from formal sources is much lower than that from informal sources and the poorer households have a significantly smaller proportion of expenditures met through credit from formal sources than the richer households. This can be seen from Table 6 which shows the 
Table 4

Difference of Means Test on Input Expenditures, Farm Expenditures and Value of Farm Output (000 Rupees) for Households With and Without Input Credit by Per Capita Expenditure Quintiles, Pakistan

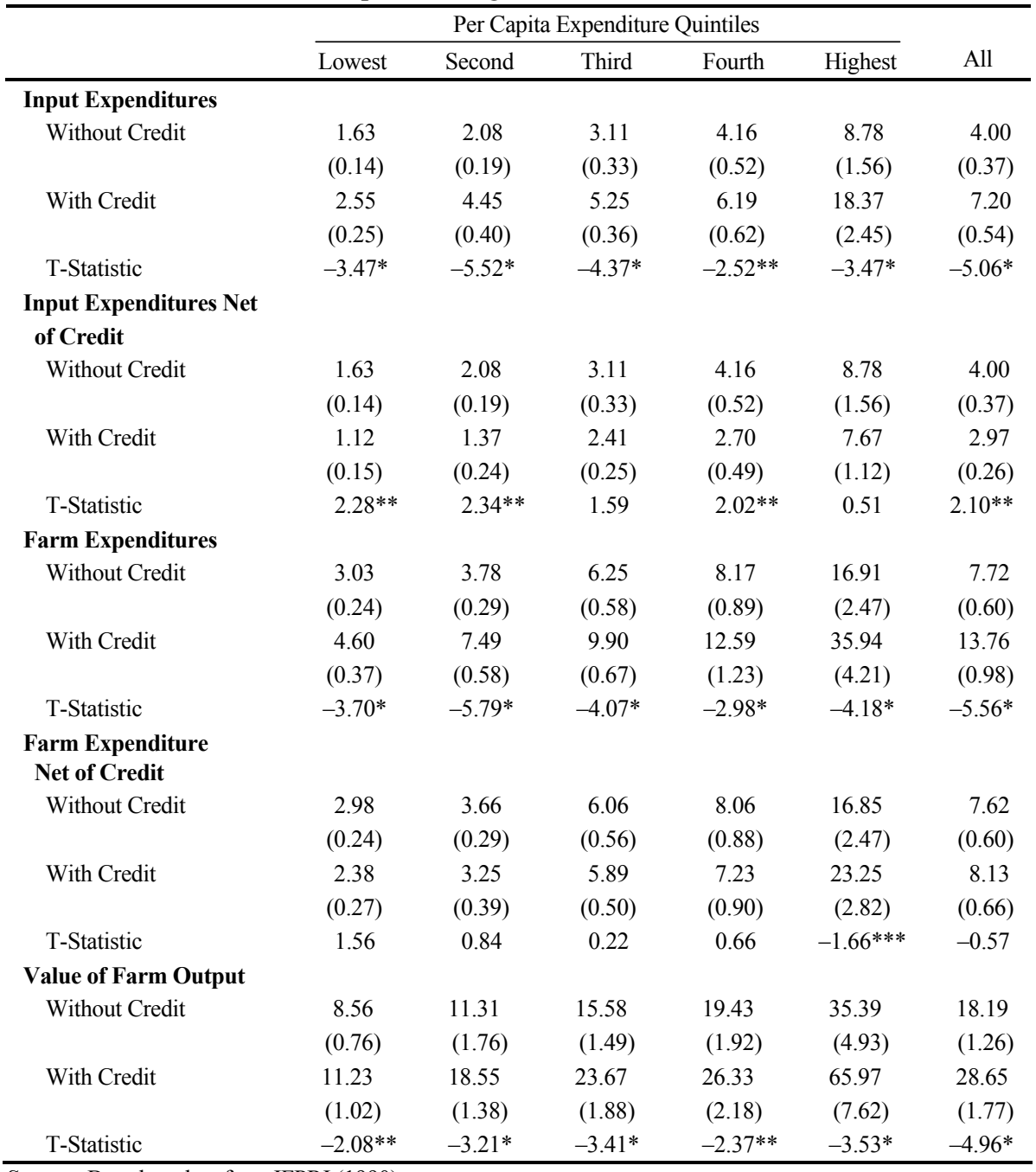

Source: Based on data from IFPRI (1990).

Notes: 1. Households using credit for seed, fertiliser and pesticides are classified as 'With credit' otherwise 'Without credit' households.

2. Figures in parenthesis are respective standard errors.

* Indicates significant at 1 percent level.

** Indicates significant at 5 percent level.

*** Indicates significant at 10 percent level. 
Table 5

Proportion of Expenditures Met Through Credit by Per Capita Expenditure Quintiles and Use of Credit and Proportion of Households Using Credit for Each Type of Expenditure

\begin{tabular}{|c|c|c|c|c|c|c|c|c|}
\hline \multirow{3}{*}{$\begin{array}{l}\text { Per Capita } \\
\text { Expenditure } \\
\text { Quintiles }\end{array}$} & \multicolumn{8}{|c|}{ Proportion of Expenditures met through Credit and Households Using Credit } \\
\hline & \multicolumn{2}{|c|}{ Input } & \multicolumn{2}{|c|}{ Capital } & \multicolumn{2}{|c|}{ Cons. inc Food } & \multicolumn{2}{|c|}{ Total } \\
\hline & $\begin{array}{c}\% \\
\text { Amount }\end{array}$ & $\begin{array}{c}\% \\
\text { Hholds }\end{array}$ & $\begin{array}{c}\% \\
\text { Amount }\end{array}$ & $\begin{array}{c}\% \\
\text { Hholds }\end{array}$ & $\begin{array}{c}\% \\
\text { Amount }\end{array}$ & $\begin{array}{c}\% \\
\text { Hholds } \\
\end{array}$ & $\begin{array}{c}\% \\
\text { Amount }\end{array}$ & $\begin{array}{c}\% \\
\text { Hholds }\end{array}$ \\
\hline $\begin{array}{l}\text { Lowest Expend. } \\
\text { Group }\end{array}$ & $\begin{array}{c}21.23 \\
(14.69)\end{array}$ & 38.71 & $\begin{array}{l}23.36 \\
(2.35)\end{array}$ & 3.23 & $\begin{array}{c}31.49 \\
(82.96)\end{array}$ & 76.50 & $\begin{array}{c}26.99 \\
(100.00)\end{array}$ & 82.03 \\
\hline $\begin{array}{l}\text { Second Expend. } \\
\text { Group }\end{array}$ & $\begin{array}{c}35.63 \\
(28.13)\end{array}$ & 56.42 & $\begin{array}{l}21.51 \\
(3.38)\end{array}$ & 7.80 & $\begin{array}{c}29.61 \\
(68.49)\end{array}$ & 76.15 & $\begin{array}{c}27.10 \\
(100.00)\end{array}$ & 87.16 \\
\hline $\begin{array}{l}\text { Third Expend. } \\
\text { Group }\end{array}$ & $\begin{array}{c}21.21 \\
(29.52)\end{array}$ & 48.62 & $\begin{array}{l}19.83 \\
(7.30)\end{array}$ & 5.96 & $\begin{array}{c}22.78 \\
(63.18)\end{array}$ & 66.06 & $\begin{array}{c}18.65 \\
(100.00)\end{array}$ & 80.28 \\
\hline $\begin{array}{l}\text { Fourth Expend. } \\
\text { Group }\end{array}$ & $\begin{array}{c}23.15 \\
(29.45)\end{array}$ & 49.08 & $\begin{array}{c}21.99 \\
(15.33)\end{array}$ & 13.30 & $\begin{array}{c}22.08 \\
(55.22)\end{array}$ & 72.48 & $\begin{array}{c}16.89 \\
(100.00)\end{array}$ & 81.19 \\
\hline $\begin{array}{l}\text { Highest Expend. } \\
\text { Group }\end{array}$ & $\begin{array}{c}18.71 \\
(30.98)\end{array}$ & 41.74 & $\begin{array}{c}23.16 \\
(41.45)\end{array}$ & 14.22 & $\begin{array}{c}14.25 \\
(24.86)\end{array}$ & 60.55 & $\begin{array}{c}12.73 \\
(100.00)\end{array}$ & 73.39 \\
\hline All Households & $\begin{array}{c}21.97 \\
(27.90)\end{array}$ & 46.92 & $\begin{array}{c}22.73 \\
(15.95)\end{array}$ & 8.91 & $\begin{array}{c}22.76 \\
(51.16)\end{array}$ & 70.34 & $\begin{array}{c}17.03 \\
(100.00)\end{array}$ & 80.81 \\
\hline
\end{tabular}

Source: Based on IFPRI (1990).

Notes: The figures in parenthesis are percentage share of credit used for each category out of total credit.

Table 6

Proportion of Farm Expenditures Met from Borrowing to Total Expenditures on Each Major Inputs

\begin{tabular}{|c|c|c|c|c|c|c|c|c|}
\hline \multirow[b]{2}{*}{$\begin{array}{l}\text { Per Capita } \\
\text { Expenditure } \\
\text { Quintiles }\end{array}$} & \multicolumn{2}{|c|}{ Seed } & \multicolumn{2}{|c|}{ Fertiliser } & \multicolumn{2}{|c|}{ Pesticides } & \multicolumn{2}{|c|}{ Total } \\
\hline & $\begin{array}{l}\text { Formal } \\
\text { Credit }\end{array}$ & $\begin{array}{c}\text { In- } \\
\text { formal } \\
\text { Credit } \\
\end{array}$ & $\begin{array}{l}\text { Formal } \\
\text { Credit }\end{array}$ & $\begin{array}{c}\text { In- } \\
\text { formal } \\
\text { Credit } \\
\end{array}$ & $\begin{array}{l}\text { Formal } \\
\text { Credit }\end{array}$ & $\begin{array}{c}\text { In- } \\
\text { formal } \\
\text { Credit } \\
\end{array}$ & $\begin{array}{c}\text { Formal } \\
\text { Credit }\end{array}$ & $\begin{array}{c}\text { In- } \\
\text { formal } \\
\text { Credit } \\
\end{array}$ \\
\hline $\begin{array}{l}\text { Lowest Expend. } \\
\text { Group }\end{array}$ & 0.19 & 16.79 & - & 31.16 & - & 33.91 & 0.26 & 6.05 \\
\hline $\begin{array}{l}\text { Second Expend. } \\
\text { Group }\end{array}$ & 0.28 & 31.76 & 0.24 & 53.88 & 0.24 & 56.82 & 0.37 & 29.49 \\
\hline $\begin{array}{l}\text { Third Expend. } \\
\text { Group }\end{array}$ & 0.15 & 15.74 & 0.09 & 38.07 & 0.63 & 36.12 & 0.73 & 23.45 \\
\hline $\begin{array}{l}\text { Fourth Expend. } \\
\text { Group }\end{array}$ & 3.06 & 16.71 & 1.33 & 35.56 & 2.30 & 35.93 & - & 10.58 \\
\hline $\begin{array}{l}\text { Highest Expend. } \\
\text { Group }\end{array}$ & 4.76 & 10.75 & 8.77 & 32.17 & 6.42 & 38.89 & 0.63 & 13.27 \\
\hline All Households & 2.79 & 15.70 & 4.12 & 36.59 & 4.73 & 39.15 & 0.49 & 14.55 \\
\hline
\end{tabular}

Source: Based on IFPRI (1990). 
proportion of farm expenditures met from borrowing to total expenditures on each of the major inputs across expenditure quintiles. The survey indicates that, for all households combined, over 18 percent of the expenditure on seed was met through borrowing. Of this, nearly 3 percent came from formal sources. In the case of fertiliser nearly 41 percent of the total expenditure was met through borrowing, of which over 4 percent came from formal sources. In the case of pesticides and water also, formal sources played a much smaller role in total borrowing. It should be reemphasised that the high proportion of informal borrowing to total expenditure in the case of these inputs, in the lower expenditure quintiles especially, is the result of respondents reporting input supplied by the landlord as informal credit. Under the law in Pakistan, the landlord is responsible for 50 percent of the cost of input of the tenants. In most cases the landlord supplies the entire quantity of inputs, adjusting the proportion of inputs over and above his legal requirements as credit to the tenant, the value of which is recovered at the time of harvest through an increased share in output.

The much smaller share of formal or institutional credit in the total borrowing for input use especially by the poorer households is brought out in much greater clarity by the data presented in Table 7. This table shows the percentage distribution of the amount of loans and the number of loans from various sources for households in different expenditure quintiles. These data show clearly that:

- Both the amount and the number of loans from institutional sources increases markedly from the lowest to the highest expenditure quintiles;

- Loans from institutional sources as a percentage of loans from all sources indicates quite clearly the reliance of the poorer households on non-institutional sources;

- Poorer households rely to a much greater extent on loans from other private sources;

- Friends and relatives are an important source of credit. However, friends and relatives are a much more important source of credit for the richer households than the poorer.

These aspects of the structure of the rural credit market in Pakistan have important implications on credit use and its impact upon poverty.

\section{CONSUMPTION SMOOTHING AND COSTLESS CREDIT? THE ROLE OF THE VILLAGE SHOPKEEPER}

The extent of credit use from different sources is obviously also the result of the price of credit or the interest rate. In the case of rural Pakistan, however, the large proportion of loans do not have an explicit price. The proportion of positive interest rate loans on an aggregate was only 6 percent of total loans. Loans from friends and relatives and other informal sources generally do not have an explicit interest charge. It is generally loans from formal sources for which some explicit interest rate is reported by 
Table 7

Percentage Distribution of Amount of Loans and Number of Loans from Formal and Informal Sources of Credit by Expenditure Quintiles and Major Sources of Credit

\begin{tabular}{|c|c|c|c|c|c|c|c|c|c|c|c|c|}
\hline \multirow{4}{*}{$\begin{array}{l}\text { Per Capita Expenditure } \\
\text { Quintiles }\end{array}$} & \multicolumn{9}{|c|}{ Sources of Formal/Informal Credit } & & & \\
\hline & \multicolumn{3}{|c|}{$\begin{array}{l}\text { Loans from Institutional } \\
\text { Sources }\end{array}$} & \multicolumn{3}{|c|}{$\begin{array}{l}\text { Loans from Friends and } \\
\text { Relatives }\end{array}$} & \multicolumn{3}{|c|}{$\begin{array}{l}\text { Loans from Other Private } \\
\text { Sources }\end{array}$} & \multicolumn{3}{|c|}{ All Sources } \\
\hline & \multicolumn{2}{|c|}{ Percent } & \multirow[b]{2}{*}{ No. } & \multicolumn{2}{|c|}{ Percent } & \multirow[b]{2}{*}{ No. } & \multicolumn{2}{|c|}{ Percent } & \multirow[b]{2}{*}{ No. } & \multicolumn{2}{|c|}{ Percent } & \multirow[b]{2}{*}{ No. } \\
\hline & Column & Row & & Column & Row & & Column & Row & & Column & Row & \\
\hline Lowest Expenditures Group & 1.9 & 6.9 & 9 & 7.2 & 26.8 & 109 & 16.3 & 66.3 & 308 & 8.8 & 100.0 & 426 \\
\hline Second Expenditures Group & 4.3 & 10.5 & 12 & 10.8 & 27.4 & 141 & 22.4 & 62.1 & 349 & 12.9 & 100.0 & 502 \\
\hline Third Expenditures Group & 17.5 & 35.5 & 33 & 12.0 & 25.2 & 140 & 17.3 & 39.3 & 306 & 15.6 & 100.0 & 479 \\
\hline Fourth Expenditures Group & 18.8 & 27.5 & 33 & 24.3 & 36.6 & 194 & 22.0 & 36.0 & 283 & 21.7 & 100.0 & 510 \\
\hline Highest Expenditures Group & 57.4 & 44.4 & 80 & 45.7 & 36.4 & 161 & 22.0 & 19.1 & 208 & 41.0 & 100.0 & 449 \\
\hline All Households & 100.00 & 31.7 & 167 & 100.00 & 32.7 & 745 & 100.0 & 35.6 & 1454 & 100.0 & 100.0 & 2366 \\
\hline
\end{tabular}

Source: Based on data from IFPRI (1990) 
Table 8

Mean Interest Rates on Positive Interest Rate Loans and Proportion of Positive Rate Loans to Total Loans

\begin{tabular}{|c|c|c|c|c|c|c|c|c|}
\hline \multirow[b]{3}{*}{$\begin{array}{l}\text { Per Capita } \\
\text { Expenditure } \\
\text { Quintiles } \\
\end{array}$} & \multicolumn{8}{|c|}{ Sources of Formal/Informal Credit } \\
\hline & \multicolumn{2}{|c|}{$\begin{array}{c}\text { Loans from Institutional } \\
\text { Sources }\end{array}$} & \multicolumn{2}{|c|}{$\begin{array}{c}\text { Loans from Friends and } \\
\text { Relatives }\end{array}$} & \multicolumn{2}{|c|}{$\begin{array}{l}\text { Loans from Other } \\
\text { Private Sources }\end{array}$} & \multicolumn{2}{|c|}{ All Sources } \\
\hline & $\begin{array}{c}\text { Mean } \\
\text { Interest } \\
\text { Rate }\end{array}$ & $\begin{array}{c}\% \text { of } \\
\text { Positive } \\
\text { Interest } \\
\text { Loans to } \\
\text { Total } \\
\text { Loans }\end{array}$ & $\begin{array}{c}\text { Mean } \\
\text { Interest } \\
\text { Rate }\end{array}$ & $\begin{array}{c}\% \text { of } \\
\text { Positive } \\
\text { Interest } \\
\text { Loans to } \\
\text { Total } \\
\text { Loans }\end{array}$ & $\begin{array}{c}\text { Mean } \\
\text { Interest } \\
\text { Rate }\end{array}$ & $\begin{array}{c}\% \text { of } \\
\text { Positive } \\
\text { Interest } \\
\text { Loans to } \\
\text { Total } \\
\text { Loans }\end{array}$ & $\begin{array}{c}\text { Mean } \\
\text { Interest } \\
\text { Rate }\end{array}$ & $\begin{array}{c}\% \text { of } \\
\text { Positive } \\
\text { Interest } \\
\text { Loans to } \\
\text { Total } \\
\text { Loans }\end{array}$ \\
\hline $\begin{array}{l}\text { Lowest Expend. } \\
\text { Group }\end{array}$ & 11.34 & 66.67 & 20.00 & 0.92 & 11.82 & 0.65 & 12.56 & 2.11 \\
\hline $\begin{array}{l}\text { Second Expend. } \\
\text { Group }\end{array}$ & 12.35 & 75.00 & - & - & 20.05 & 0.86 & 12.49 & 2.39 \\
\hline $\begin{array}{l}\text { Third Expend. } \\
\text { Group }\end{array}$ & 14.87 & 75.76 & - & - & 45.78 & 0.65 & 15.26 & 5.64 \\
\hline $\begin{array}{l}\text { Fourth Expend. } \\
\text { Group }\end{array}$ & 12.56 & 84.85 & - & - & 51.07 & 0.71 & 12.89 & 5.88 \\
\hline $\begin{array}{l}\text { Highest Expend. } \\
\text { Group }\end{array}$ & 12.21 & 76.25 & 10.00 & 0.62 & 63.15 & 0.96 & 12.45 & 14.25 \\
\hline All Households & 12.73 & 77.25 & 14.31 & 0.27 & 33.77 & 0.76 & 13.01 & 6.00 \\
\hline
\end{tabular}

Note: - Indicates that there were no positive interest rate loans reported. 
The bulk of the credit is, however, reportedly obtained at a zero nominal rate of interest. The data from the IFPRI survey reveals that a considerable portion of this credit is obtained from the village shopkeeper in the form of in kind consumption goods. The data in Table 9 show that 82 percent of all borrowing households and over 57 percent of all borrowing was in the form of borrowing from shopkeepers. This extremely important source of credit in rural Pakistan has been largely ignored in the research on rural credit issues. The village shopkeeper provides a convenient means of

Table 9

Proportion of Shopkeeper Credit to Total Credit and Total Consumption by Per Capita Expenditure Quintiles, Pakistan

\begin{tabular}{|c|c|c|c|c|c|c|}
\hline & \multicolumn{6}{|c|}{ Per Capita Expenditure Quintiles } \\
\hline & Lowest & Second & Third & Fourth & Highest & All \\
\hline \multicolumn{7}{|c|}{ Shopkeeper Credit to Total Credit } \\
\hline$\%$ Hholds & 86.81 & 86.19 & 79.46 & 83.27 & 74.30 & 82.00 \\
\hline \multirow[t]{2}{*}{$\%$ Amount } & 73.88 & 66.59 & 58.93 & 48.47 & 38.42 & 57.17 \\
\hline & $(2.37)$ & $(2.19)$ & $(2.46)$ & $(2.31)$ & $(2.48)$ & $(1.11)$ \\
\hline \multicolumn{7}{|c|}{ Households with Shopkeeper Credit Only } \\
\hline$\%$ Amount & $\begin{array}{l}85.11 \\
(1.66)\end{array}$ & $\begin{array}{l}77.26 \\
(1.70)\end{array}$ & $\begin{array}{l}74.16 \\
(2.01)\end{array}$ & $\begin{array}{l}58.21 \\
(2.24)\end{array}$ & $\begin{array}{l}51.72 \\
(2.73)\end{array}$ & $\begin{array}{l}69.72 \\
(1.00)\end{array}$ \\
\hline \multicolumn{7}{|c|}{ Shopkeeper Credit to Total } \\
\hline \multicolumn{7}{|c|}{ Consumption Expenditure } \\
\hline$\%$ Hholds & 64.97 & 73.33 & 65.08 & 67.94 & 58.73 & 66.01 \\
\hline$\%$ Amount & $\begin{array}{l}26.17 \\
(1.45)\end{array}$ & $\begin{array}{l}29.01 \\
(1.43)\end{array}$ & $\begin{array}{l}24.88 \\
(1.40)\end{array}$ & $\begin{array}{l}24.47 \\
(1.31)\end{array}$ & $\begin{array}{l}20.53 \\
(1.34)\end{array}$ & $\begin{array}{l}25.01 \\
(0.62)\end{array}$ \\
\hline \multicolumn{7}{|c|}{ Households with Shopkeeper Credit Only } \\
\hline$\%$ Amount & $\begin{array}{l}40.28 \\
(1.49)\end{array}$ & $\begin{array}{l}39.55 \\
(1.41)\end{array}$ & $\begin{array}{l}38.23 \\
(1.45)\end{array}$ & $\begin{array}{l}36.02 \\
(1.33)\end{array}$ & $\begin{array}{l}34.96 \\
(1.58)\end{array}$ & $\begin{array}{l}37.89 \\
(0.65)\end{array}$ \\
\hline
\end{tabular}

Source: Based on data from IFPRI (1990).

Note: Figures in parentheses are respective standard errors.

consumption smoothing for the rural households. The shopkeeper's intimate knowledge of the borrower and his ability to enforce repayment ensures low default. Such credit generally has no explicit interest charged. It is short term in nature and repayment is tied either to the crops cycle or to the monthly pattern of salaries and wages. Table 9 shows that over 25 percent of the total consumption expenditures are met through borrowing from shopkeepers. For households that report only the use of shopkeeper credit this percentage is closer to 38. Generally household in the lower expenditure quintiles report a higher dependence on shopkeeper credit than do households in the highest. However, even in the highest expenditure quintiles the percentage of expenditures met through shopkeeper credit is significantly large. While it is difficult to quantify the implicit markup in prices on goods sold on credit by these shopkeepers it is generally believed that such mark-ups are considerable keeping in view the generally short term nature of the transactions.

The impact of shopkeeper credit on household and per capita consumption expenditure across different expenditure quintiles can be seen from Table 10 which was derived in essentially the same way as Table 2 above; ${ }^{7}$ except that in Table 2 total

${ }^{7}$ Computations for food expenditure with and without shopkeeper credit turned up patterns similar to those reported in Table 2 for overall credit. 
Table 10

Difference of Means Test on Consumption Expenditures (000 Rupees) for Households with and without Shopkeeper Credit by Per Capita Expenditure Quintiles, Pakistan

\begin{tabular}{lcccccc}
\hline & \multicolumn{5}{c}{ Per Capita Expenditure Quintiles } \\
\cline { 2 - 7 } & Lowest & Second & Third & Fourth & Highest & All \\
\hline Household Consumption & & & & & & \\
Expenditures & & & & & & \\
Without Credit & 11.76 & 16.45 & 15.18 & 22.51 & 33.82 & 20.59 \\
& $(0.57)$ & $(1.06)$ & $(0.83)$ & $(1.48)$ & $(3.85)$ & $(1.07)$ \\
With Credit & 13.67 & 17.02 & 16.64 & 18.73 & 22.65 & 17.64 \\
& $(0.42)$ & $(0.61)$ & $(0.49)$ & $(0.58)$ & $(1.27)$ & $(0.33)$ \\
T-Statistic & -2.72 & -0.48 & -1.61 & 2.86 & 3.14 & -3.30 \\
Household Consumption Expenditure & & & & & & \\
Net of Shopkeeper Credit & & & & & & \\
Without Credit & 11.76 & 16.45 & 15.18 & 22.51 & 33.82 & 20.59 \\
& $(0.57)$ & $(1.06)$ & $(0.83)$ & $(1.48)$ & $(3.85)$ & $(1.07)$ \\
With Credit & 8.40 & 10.34 & 10.46 & 12.28 & 15.55 & 11.31 \\
& $(0.36)$ & $(0.45)$ & $(0.43)$ & $(0.51)$ & $(1.15)$ & $(0.28)$ \\
T-Statistic & 5.19 & 6.18 & 5.60 & 8.13 & 5.21 & 10.75 \\
Per Capita Consumption Expenditure & & & & & & \\
Without Credit & 1.31 & 1.78 & 2.08 & 2.52 & 3.66 & 2.34 \\
& $(0.03)$ & $(0.04)$ & $(0.06)$ & $(0.08)$ & $(0.21)$ & $(0.07)$ \\
With Credit & 1.29 & 1.71 & 2.03 & 2.38 & 3.05 & 2.07 \\
& $(0.02)$ & $(0.02)$ & $(0.04)$ & $(0.06)$ & $(0.13)$ & $(0.03)$ \\
T-Statistic & 0.53 & 1.37 & 0.74 & 1.28 & 2.67 & 4.14 \\
Per Capita Consumption Expenditure & & & & & & \\
Net of Shopkeeper Credit & & & & & & \\
Without Credit & 1.31 & 1.78 & 2.08 & 2.52 & 3.66 & 2.34 \\
With Credit & $(0.03)$ & $(0.04)$ & $(0.06)$ & $(0.08)$ & $(0.21)$ & $(0.07)$ \\
T-Statistic & 0.78 & 1.04 & 1.25 & 1.53 & 2.02 & 1.31 \\
& $(0.02)$ & $(0.03)$ & $(0.04)$ & $(0.05)$ & $(0.10)$ & $(0.03)$ \\
& 13.63 & 13.15 & 12.28 & 10.19 & 7.75 & 17.09 \\
\hline
\end{tabular}

Source: Based on data from IFPRI (1990).

Notes: 1. Households using shopkeeper loan for expenditures are classified as 'With Credit' otherwise 'Without Credit' households.

2. Figures in parenthesis are respective standard errors.

credit was considered whereas here only credit from shopkeepers is considered. From Table 10 it can be seen that households without such credit either have statistically significantly lower consumption expenditures or the mean levels are not dissimilar to households with access to shopkeeper credit. However, when expenditures met from such shopkeeper credit are netted out from overall expenditures we find that households without such credit have statistically significantly higher levels of mean consumption expenditures both at the household and per capita level. This implies that a significant portion, indicated in Table 9 above, of rural households rely heavily on shopkeeper credit to maintain their consumption at the levels of their peers in the expenditure 
quintiles to which they belong.

This shopkeeper credit is however, a special case. In most instances it is a matter of convenience for both the shopkeeper and the borrower to consolidate the small payments accrued over say the period of one month to one single payment on pay day. However, the consumption smoothing aspect of this credit transaction especially in the absence of rural banking services is considerable. Moreover, given the total size of such credit transactions this important segment of the rural credit market should not be ignored in any serious analysis or considerations of policy-making.

\section{CONCLUSIONS}

These data seem to confirm the welfare enhancing and poverty reducing linkages of rural credit use in Pakistan. The availability of credit has a very important role to play in allowing households, especially poor ones, to smooth consumption, while at the same time, the adoption of modern technology requires that credit be available to finance the purchase of inputs and to allow farming households to bear more risk. One of the main findings of this paper is that consumption credit is used in Pakistan by households in the lowest quintile to bring their food consumption up to the levels achieved by their peers who do not use credit. The food expenditure of these households after netting out the credit financed component would leave them extremely poor. This paper finds that based on the head count measure about a fifth of rural households in Pakistan could be classified as poor or below the poverty line. However, when expenditures met through credit are netted out, about half the households drop below the poverty line, implying that over 30 percent of rural households manage to stay above the poverty line through credit use. There are also some interesting regional variations. It appears that credit availability is particularly effective in Sindh, because without it three out of five households would be in poverty whereas with credit, only about one household in eight is in poverty. The gains in Punjab and NWFP are not as striking but are still significant.

The difference of means tests for key items of consumption expenditure between credit using households and those that do not for households in the same expenditure quintile found similar results. It turns out that there are no statistically significant differences in mean household expenditures, between households with credit and those without credit, in the middle expenditure quintiles. However, significant differences arise in the lowest expenditure quintile where the mean expenditures of households with credit are significantly higher than households without credit and in the highest expenditure quintile where the mean expenditures of households with credit are significantly lower.

This study shows the overwhelming importance of shopkeeper credit in meeting the consumption needs. This is an area that has simply not received the attention it deserves because it appears from our work, that four out of five borrowing households were getting credit from shopkeepers and about three-fifths of all borrowing was from 
shopkeepers. The shopkeeper's intimate knowledge of his customers enables him to minimise risks and ensure timely repayment. Such credit is generally short term in nature and there are no explicit interest charges; repayment being tied to the crop cycle. This study finds that a fourth of total consumption expenditures are met through borrowing from shopkeepers. For households that report only the use of shopkeeper credit, this percentage is closer to two-fifths. As one would expect, households in the lower expenditure quintiles generally report a higher dependence on shopkeeper credit than do households in the highest; although even in the highest quintiles the percentage of expenditures met through shopkeeper credit is significantly large. This paper notes that households without such credit either have statistically significantly lower consumption expenditures or consume at about the same mean levels as households who get shopkeeper credit. However, when expenditures met from such shopkeeper credit are netted out from overall expenditures we find that households without such credit have statistically significantly higher levels of mean consumption expenditures both at the household and per capita level.

But while shopkeeper credit helps stabilise consumption, do the poor have to pay a heavy price for its availability? While it is difficult to quantify the implicit mark-up in prices on goods sold on credit by village shopkeepers it is generally believed that such mark-ups are considerable especially in view of the generally short term nature of the transactions. Unfortunately, very little hard evidence is available, and this should certainly be an area for future research.

The importance of credit in production is brought out by results based on both a wider definition of credit which incorporates the essential elements of the fungibility of credit and the jointness of consumption and production decisions, (so that a household is defined as "with credit" if it obtained credit for any purpose) and then a narrower one where only households that borrowed for farm production are defined as with credit. Input expenditures are defined to include only expenditures on seed, fertiliser and pesticides whereas farm expenditures include all types of expenditure on the farm. In the case of both input expenditures and farm expenditures, households with credit, defined using the wider definition, generally have a significantly higher level of mean expenditures than those households without credit in the three lowest expenditure quintiles. Moreover, when credit use is netted out of expenditures, we find that the mean level of expenditures are generally similar. This implies that households in the lower expenditure quintiles increase their mean input and farm expenditures through credit use. The poor seem to be using consumption credit to raise their consumption levels to achieve parity with their peers. But where production credit is concerned, those who can get it appear to be using it to raise input expenditures to levels significantly above those of their peers.

These findings, of greater input use are strongly reinforced if the stricter definition of households with credit is applied. In this case households that use credit for 
seed, fertiliser and pesticides are classified as "with credit" and those that do not, are classified as "without credit". When this is done, it appears that households with input credit have significantly higher levels of mean input and farm expenditures in each expenditure quintile. Moreover, when credit is netted out of expenditures, the mean input expenditures of households without credit are either higher or similar to those defined as "with credit". The strongest result is that households with credit have significantly higher values of farm output in each expenditure quintile, which shows that credit use has a positive welfare impact in rural Pakistan.

Another significant finding is that while within the different types of farm expenditures borrowing from both formal and informal sources is used, generally, the proportion of expenditure met from borrowing from formal sources is much lower than that from informal sources and poorer households have a significantly smaller proportion of expenditures met through credit from formal sources than the richer households. For all households combined, about a fifth of the expenditure on seed was met through borrowing; only about one-thirtieth of which came from formal sources. In the case of fertiliser nearly two-fifths of the total expenditure was met through borrowing, of which barely over one twentieth came from formal sources. In the case of pesticides and water also, formal sources played a much smaller role in total borrowing. It needs to be emphasised that the high proportion of informal borrowing to total expenditure in the case of these inputs, in the lower expenditure quintiles especially, is the result of respondents reporting inputs supplied by the landlord as informal credit. Under the law in Pakistan, the landlord is responsible for 50 percent of the cost of inputs of his tenants. In most of the cases the landlord supplies the entire quantity of inputs, adjusting the proportion of inputs over and above his legal requirements as credit to the tenant, the value of which is recovered at the time of harvest through an increased share in output.

As far as the use of institutional credit in different quintiles is concerned, a number of interesting trends emerge:

(i) Both the amount and the number of loans from institutional sources increase markedly from the lowest to the highest expenditure quintiles;

(ii) Loans from institutional sources as a percentage of loans from all sources indicates quite clearly the reliance of the poorer households on non-institutional sources;

(iii) Poorer households rely to a much greater extent on loans from other private sources;

(iv) Friends and relatives are an important source of credit. However, friends and relatives are a much more important source of credit for the richer households than the poorer.

The irony is that while the Government of Pakistan has over the past 25 years 
carried out a policy of disbursing large amounts of highly subsidised credit to facilitate the adoption of the Green Revolution technology by small farmers, the larger size farmers and the richer households seem to dominate its use.

The extent of credit use from different sources is obviously also the result of the price of credit or the interest rate. In the case of rural Pakistan, however, the large proportion of loans do not have an explicit price. The proportion of positive interest rate loans on an aggregate is barely one twentieth of total loans. Loans from friends and relatives, shopkeepers and other informal sources generally do not have an explicit interest charge.

It is clear that small farmers and tenants, in particular, are paying a higher price by being shut out of the formal credit market. Therefore a formal analysis of what determines access to institutional credit by farmers is warranted.

The detailed econometric analyses presented in Malik (1999) show that significant poverty alleviation is possible in rural Pakistan through a better functioning rural credit market. Major welfare gains can arise from higher input use, and resultant higher productivity, as well as through improved and more efficient consumption smoothing. The analysis indicates the strong need for a reduction in borrowers' transaction costs, both explicit and implicit, through better flow of information, review of the existing collateral requirements, and simplification of the loan application procedure for institutional credits. And the need to facilitate the development of indigenous credit mechanisms is just as urgent.

\section{REFERENCES}

Desai, Bhupat M., and John W. Mellor (1993) Institutional Finance for Agricultural Development: An Analytical Survey of Critical Issues. (Food Policy Review 1.) Washington, D. C.: International Food Policy Research Institute.

IFPRI (1990) Panel Survey of Rural Households in Selected Districts of Pakistan, Round 13. Washington, D. C.: International Food Policy Research Institute.

Malik, S. J. et al. (1989) Differential Access and the Rural Credit Market in Pakistan: Some Recent Evidence. The Pakistan Development Review 28:4 709716.

Malik, S. J. (1990) Report on the Benchmark Credit Survey. International Food Policy Research Institute, Washington, D. C (Report).

Malik, S. J. (1999) Poverty and Rural Credit: The Case of Pakistan. Islamabad: Pakistan Institute of Development Economics.

Zeller, M., G. Schrieder, J. von Braun, and F. Heidhues (1993) Rural Finance for Food Security of the Poor: Concept, Review, and Implications for Research and Policy. International Food Policy Research Institute, Washington, D. C. (Draft Occasional Paper.) 